\title{
Leader
}

\section{Cell proliferation in gastrointestinal mucosa}

\author{
Wai Man Wong, Nicholas A Wright
}

\begin{abstract}
Gastrointestinal cell proliferation plays an important role in the maintenance of the integrity of the gastrointestinal system. The study of gastrointestinal proliferation kinetics allows a better understanding of the complexity of the system, and also has important implications for the study of gastrointestinal carcinogenesis. Gastrointestinal stem cells are shown to be pluripotential and to give rise to all cell lineages in the epithelium. Carcinogenesis in the colon occurs through sequential mutations, possibly occurring in a single cell-the stem cell.

(F Clin Pathol 1999;52:321-333)
\end{abstract}

Keywords: gastrointestinal mucosa; cell proliferation; stem cells

Mucosal cell proliferation is essential for the maintenance of the integrity of the gastrointestinal system. The proliferation rates of the gastrointestinal system are high, second only to the haemopoietic system, making it possible and practical to obtain accurate measurements; however, unlike the haemopoietic system, the tissue architecture allows a detailed analysis of its kinetic organisation. The study of gastrointestinal proliferation kinetics allows us to have a better understanding of the complexity of the system, and also has important implications for the study of gastrointestinal carcinogenesis, since enhanced mucosal proliferation had long been recognised as a promoter of carcinogenesis. Cell division in the gastrointestinal tract is confined to an anatomically discrete zone-the proliferative compartment. This readily identifiable anatomical position, together with its high proliferation rates, makes it an ideal system for the study of epithelial growth control and stem cell biology: stem cells in the gastrointestinal mucosa are pluripotent, having the ability to give rise to cells of more than one lineage. It is probable that stem cells are ultimately involved in carcinogenic mechanisms because once they acquire the sequential mutations required for the development of the neoplastic phenotype, it is likely to be permanent in all the daughter cells.

In this paper, we will address several issues in gastrointestinal proliferation: (1) the cell cycle; (2) stem cell concepts; (3) methods employed to measure proliferation in the gastrointestinal tract; (4) the cell production rate in the gastro- intestinal mucosa; (5) the control of cell proliferation; (6) hypoproliferative and hyperproliferative states in the gastrointestinal tract; and (7) cell proliferation in gastrointestinal carcinogenesis.

\section{The cell cycle}

The process of cell division is divided into four different phase. The stage that can be easily recognised is mitosis or the $M$ phase of the cell cycle. Cells then will enter a stage called $G_{1}$, which is most variable in duration, and various biochemical events occur at this stage which regulate the duration and the termination of this phase. The next phase of the cell cycle is the $S$ phase, in which DNA synthesis occurs, and immediately before mitosis, cells enter a short, second gap phase, known as $G_{2}$, where the cell prepares for mitosis and assembles the spindle proteins. The duration of the cell cycle is mainly determined by the length of the $G_{1}$ phase, the other phases being relatively constant. The great variability in the length of the $\mathrm{G}_{1}$ in different tissues suggests that it is the key element in the control of the cell cycle. It has been suggested that in late $G_{1}$, genetically controlled event triggers the initiation of DNA synthesis, sometimes referred to as a transition probability event; the probability of passing through this transition is high in the gut, and thus the cells cycle rapidly. ${ }^{1}$ In the gastrointestinal system, cells eventually leave the cell cycle and differentiate, but in some tissues they may enter a resting phase, known as $G_{0}$, although there is little evidence of a $G_{0}$ phase in the gut. Differentiated cells are generally believed to lose their proliferative capacity, but in extreme conditions, they can be persuaded to enter the cell cycle again by expression of, for example, SV40T antigen. ${ }^{2}$

\section{The stem cell concept}

Stem cells are the cells that lay down the various cell lineages which form our tissues and organs during embryogenesis. They are responsible for the continued production of cells in tissues where constant renewal is a feature, such as the bone marrow and the gastrointestinal tract, and epithelial stem cells are especially important in the sense that most human tumours are derived from epithelial tissues, and that stem cells are considered by many to be intimately involved in carcinogenic mechanisms. Stem cells are pluripotent, or 
have the ability to give rise to cells of more than one lineage, and consequently these cells should be the target of gene therapy, because then the effect of the treatment is likely be permanent rather than transitory, as when expression is confined to the daughter cells $\left({ }^{3}\right.$ and Del Buono et al, unpublished data).

An important first concept is that stem cells in the gut are located in specific sites, at the origin of the cell flux; thus the base of the intestinal crypt is thought to house the stem cells. Second, stem cells form a minority population within the proliferating cell compartment of the crypt or gastric gland. The clonogenic population, or the number of cells capable of regenerating a crypt after severe irradiation damage, is small compared with the number of proliferating cells in the crypt, ${ }^{4}$ and experiments with mutagens, which induce phenotypic changes in colonic and small intestinal crypts, can be best explained by mutations induced in a single stem cell, or in a very small number. Third, the concept of a few basally sited crypt stem cells which supply progeny to the proliferative compartment of dividing transit cells has emerged; these cells have long cycle times compared with the other proliferating cells, divide asymmetrically, and the daughter cells migrate up the crypt, undergoing a series of divisions before leaving the cell cycle to begin differentiation towards the top of the crypt. The migration kinetics in the gastric glands is assumed to be similar, except that this occurs in two directions, upwards towards the foveola and downwards to the base of the gland.

Several experimental models support the concept of pluripotent stem cells in the gut. Kirkland showed that, in the HRA19 cell line (which derived from a moderately differentiated human colorectal carcinoma), single cells were able to differentiate into all cell lineages in the colon. ${ }^{5}$ Furthermore, when these cloned epithelial cells were grafted into the subcutaneous tissue of the nude mouse, within four months a tumour forms which reproduces the histological appearances of the original tumour and contains columnar, goblet, and endocrine cells. Thus a single epithelial cell, even though it is malignant, can give rise to all cell types seen in the colorectal epithelium.

An interesting model to examine the stem cell phenomenon is the chimaeric mouse, produced by fusion of two fertilised zygotes to form a single individual. One such model is where one strain binds the lectin Dolichos biflorus agglutinin (DBA), ${ }^{6}$ and staining the small intestine with DBA shows that the crypts are either positive or negative-there are no mixed crypts. This important experiment indicates that each crypt forms a clonal population-crypts are each derived from a single cell. In neonatal animals, up to about two weeks, mixed crypts are found but these quickly disappear: thus it appears that in development, crypts are polyclonal. ${ }^{7}$ But by an obscure process, crypts sort themselves out to become monoclonal. It has been proposed that "cleansing" of these crypts includes overgrowth and extrusion of one stem cell lineage by the other, or, since there is extremely active division of crypts by fission at this time, it is possible that segregation of the lineages could occur by crypt fission.

The study of the spread of mutated stem cell crypts in mice after a single dose of a mutagen also gives rise to a similar conclusion - that is, a single stem cell can give rise to all crypt lineages, in both colon and small intestine. ${ }^{89}$

In the stomach, the first study to address this problem was that of Thompson et al, using $\mathrm{XY} / \mathrm{XO}$ mouse chimaeras. ${ }^{10}$ The male component of the chimaera was identified using in situ hybridisation with a digoxigenin labelled probe, pY353, which identified the high repetitive sequences of the mouse $\mathrm{Y}$ chromosome. Gastric glands in the mouse, as with crypts in the intestine, were found to be clonally derived. The findings were confirmed by Tatematsu et al, using $\mathrm{C} 3 \mathrm{H} / \mathrm{HeN}<->\mathrm{Balb} / \mathrm{c}$ chimaeric mice and differentiating the gastric glands using a C3H stain specific antigen. ${ }^{11}$

Novelli et al described a very rare individual who showed the genotype $\mathrm{XO} / \mathrm{XY},{ }^{12}$ who by coincidence also had familial adenomatous polyposis (FAP), for which he had undergone a prophylactic total colectomy at 32 years of age. Pathology material was available for analysis. A combination of karyotyping and fluorescent in situ hybridisation (FISH) on the patient's peripheral blood lymphocytes confirmed that he was a mosaic, and also showed the $\mathrm{Y}$ chromosome to be dicentric. The karyotype was 45,X/46,Xdic (Y)(Ypter->cen->Yq11.23: :Yp11.3) and approximately $20 \%$ of peripheral blood lymphocytes were XO. A frameshift mutation at codon 1309 was also demonstrated by protein truncation assay of his adenomatous polyposis coli (APC) gene.

Using Y chromosome specific probes to perform in situ hybridisation on histological sections of small and large intestine of this individual, intestinal crypts were found to be composed of either XY or XO cells. From the thousands of intestinal crypts examined, only four mixed crypts were seen in otherwise pure $\mathrm{XY}$ patches. The patches of XO crypts were irregular in shape and patch size varied widely (mean patch width 1.85 crypts, range 1 to 14 crypts). Crypts examined at the patch border showed no mixed $\mathrm{XO} / \mathrm{XY}$ cellularity and all epithelial cell lineages could be directly visualised as XO or XY, including columnar cells, goblet cells, and endocrine cells. Thus normal human intestinal crypts are clonal populations, derived from a single multipotential stem cell.

We can therefore conclude that in both animals and man there is evidence to show that the gastrointestinal stem cell has a distinct repertoire which includes all the main cell lineages observed in the gut; and is also responsible for the production of new intestinal crypts.

\section{Methods of measuring cell proliferation in the gastrointestinal tract}

The accurate assessment of cell turnover in humans is important for the understanding of a wide variety of physiological and pathological processes. Radioactive thymidine incorporation labels newly synthesised DNA, relying on 
the assumption that every DNA synthesising cell exposed to the thymidine will incorporate it in a dose dependent manner. ${ }^{13}$ This is not always the case: first, the amount of unlabelled thymidine (cold thymidine) in the sample may affect the proliferation rate if present in large amounts ${ }^{14}{ }^{15}$; there is also some evidence that some cells may have the ability to retain the thymidine in a non-exchangeable form and incorporate the label at a later date. ${ }^{16}$ Second, there is a theoretical risk of radiation induced nuclear damage if high specific activity thymidine is used or the study is over a prolonged period. Third, reutilisation of used thymidine from dying or differentiated cells may also give misleading results. Finally, there is the possibility that thymidine may be incorporated into mitochondrial DNA or that DNA repair may be detected rather than scheduled DNA synthesis. Furthermore, the technique, which involves autoradiography, is very labour intensive.

An alternative method is to count mitotic figures or arrested metaphases in microdissected crypts. This can give similar results, but is far quicker and in many ways also more robust. ${ }^{17}$ The great advantage of such techniques is that results are expressed on a per crypt basis, so that one does not need to count interphase cells. Furthermore, the geometric disadvantages associated with scoring crypt sections are avoided. A great advantage of the technique is that it can account for all the factors involved in cell renewal-that is, phase duration, growth fraction, and compartment size (see below). Although there are far fewer mitotic figures than DNA synthesising cells, microdissection of crypts enables all the figures in the entire crypt to be scored, and all the crypts in a sample can be quantified. In animal experiments, the gold standard is the quantification of the rate of entry of cells into mitosis using a metaphase arrest agent such as vincristine, which defines the crypt cell production rate (CCPR). If the number of animals is limited, an augmented mitotic index can be obtained by sampling two hours after vincristine administration. This method is theoretically less robust, but it is more precise and allows complex multivariate analysis.

In human studies, the use of a metaphase agent in vivo is unethical nowadays, but scoring mitotic figures in microdissected material is still a viable alternative. This is often more preferable to the several in vitro methods available for the assessment of biopsies, which are labour intensive, require the immediate incu-

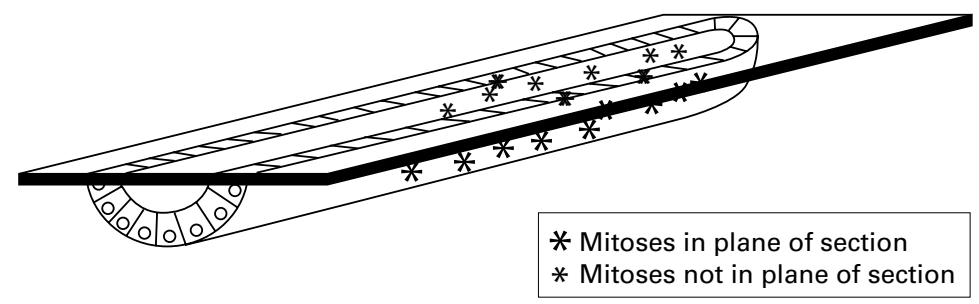

Figure 1 A diagrammatic representation of a crypt in histological section illustrating the point that many more mitoses are seen in whole, microdissected crypts that in a single plane of section (from Goodlad et al, ${ }^{31}$ with permission). bation of the tissue, and may not even be reliable. ${ }^{18}$

The use of immunohistochemical techniques enables the visualisation of specific cell cycle related antigens in tissues, with the important advantage of preserving the spatial orientation of cells. PC10 is a monoclonal antibody which recognises the proliferating cell nuclear antigen (PCNA), a protein associated with $\delta$ DNA polymerase and found in cycling cells. ${ }^{19-22}$ However, the results generated are highly dependent on the previous treatment of the tissue. It has been shown that PCNA immunoreactivity in non-neoplastic tissue is greatly reduced after 48 hour of fixation in formalin, and is virtually abolished after fixation for 72 hours. Staining is also greatly reduced or abolished if sections are heated to assist adherence to glass slides. ${ }^{23}$ Furthermore, the antigen can also be expressed in tissue adjacent to a tumour or in tissues after growth factor treatment. The Ki67 antigen is a protein of unknown function, which has been shown to be a reliable marker of cells within the cell cycle. ${ }^{24}$ Its application was seriously affected by its requirement for frozen tissue, but recent developments have shown that a new monoclonal antibody against the same antigen, MIB-1, can be applied to conventional, paraffin embedded tissue. MIB-1 has been extensively studied in human tissues ${ }^{25-28}$; MIB-5, a more recently produced antibody, also shows positive staining in animal tissues. ${ }^{29} \mathrm{Ki} 67$ is a good marker of cells in all phases of the cell cycle, and thus is a good measurement of the proportion of cells in cycle, the growth fraction. ${ }^{24}$

There are still two problems associated with all the antibody techniques. The first is the difficulty in standardising immunohistochemical techniques and in setting thresholds for scoring a cell as labelled or unlabelled. The second is related to the problem of scoring the sections, as the results may be confounded by concomitant changes in crypt size. These problems can be avoided if the whole crypt is quantified by a microdissection based technique. ${ }^{30}$ This method was validated by the study of human intestinal biopsy samples, as well as in animal studies. ${ }^{31}$ Although the method counts cells in mitosis only, this is compensated for by the ability to see and score every mitosis in the crypts, so the numbers counted are quite high. It was estimated that there were up to 15 times more mitoses in whole crypts as were seen in a crypt section (fig 1 ). Biopsies need little special treatment, apart from the use of Carnoy's solution for fixation. The tissue can then be stored in $70 \%$ alcohol for years. Crypt size and area can be determined by the use of a drawing tube, as can the position of mitoses in the crypt. Quantification of the drawings can be performed by using an image scanner and image analysis program. Combining all the above factors, scoring mitoses in microdissected crypts appears to be the method of choice for the study of gastrointestinal proliferation. Positional analysis can also be obtained accurately with the help of confocal microscopy in microdissected crypts. ${ }^{32}$ 

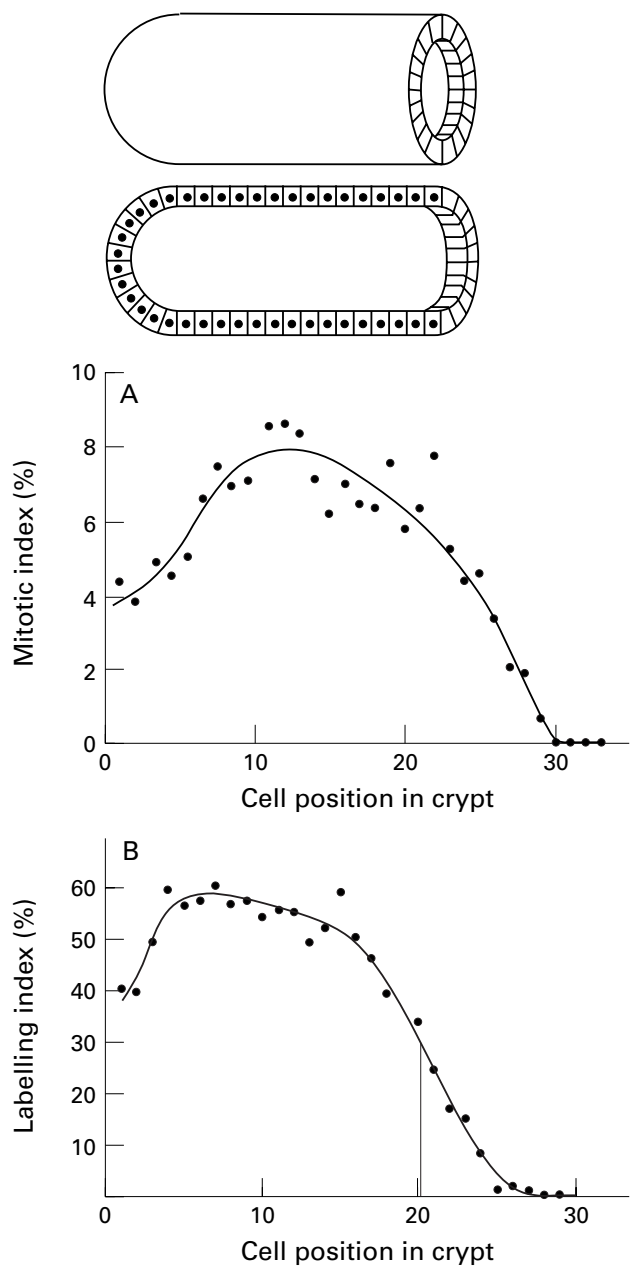

Figure 2 (A) The principle behind the construction of a mitotic index distribution curve. Axially sectioned crypts are selected in sufficient number and, at each cell position, the mitotic index is measured and plotted against cell position. This shows a mitotic index distribution curve for the rat. (B) This is a tritiated thymidine labelling index curve for the rat jejunal crypt (from Wright et al, ${ }^{59}$ with permission).

PROLIFERATIVE INDEX DISTRIBUTION CURVES

A useful modification of the proliferative index measurement in the gastrointestinal tract is the construction of a proliferative index distribution curve (fig 2 ). There are numerous kinetic parameters which derive from it, and even if tritiated thymidine cannot be used, as in human studies, the analysis of mitotic index distribution curves has allowed a comprehensive investigation of crypt cell kinetics in, for example, coeliac disease. ${ }^{33} 34$

The index distribution curve is drawn by selecting large number of axially sectioned

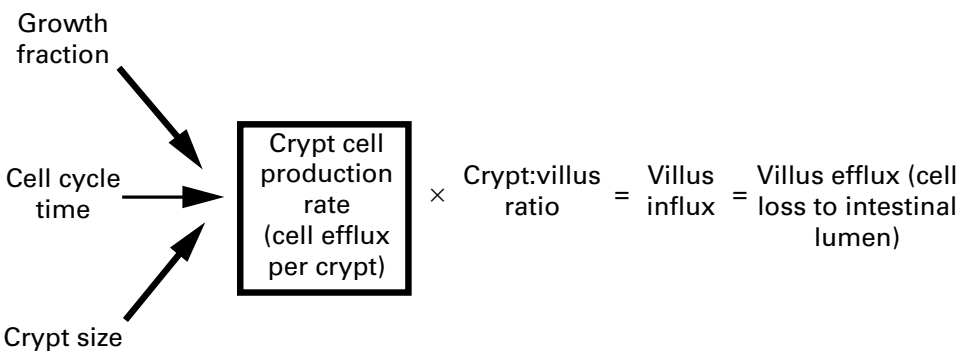

Figure 3 The kinetic factors which determine the crypt cell production rate and the net influx of cells onto the villus in the small intestine. crypts. Then, starting at cell position 1 in the column of cells, the cells in this crypt column are individually identified and a record kept of which cell positions contain mitotic or labelled cells, counting up to the crypt:villus junction, and the length of the crypt column is also recorded. If this is done for sufficiently large number of crypts (about 100 crypts per curve is a minimum), the labelling/mitotic index distribution curve can be drawn (fig 2 ).

There are several advantages to this analysis: (1) the proliferative activity within the crypt can be easily assessed; (2) an estimate can be made of the crypt growth fraction; and (3) the mitotic index distribution curve is the first step in the construction of the cumulative birth rate curve, ${ }^{36}$ which in turn leads to the derivation of migration rates and transit times at each cell position in the crypt, and to an estimate of the crypt cell production rate.

\section{The cell production rate in the} gastrointestinal tract

Cell proliferation in the gut can be increased or decreased in a wide variety of different circumstances, in response to physiological stimuli such as altered food intake and also in pathological conditions. A classic example is the adaptation to gluten induced cell loss in coeliac disease.

There are various ways in which cell proliferation can be adjusted to increase or decrease cell production (fig 3 ). The crypt cell production rate, or the crypt efflux, is a function of the growth fraction, cell cycle time, and crypt size. Then the product of the crypt cell production rate and the numbers of crypts per villus - the crypt:villus ratio-will give a measurement of the villus influx. Any change of the above factors will affect the cell proliferation in the gut.

THE CELL CYCLE TIME

In rodent tissue, the cell cycle time in the small intestine is short, but there is still room for an increase in the cell production rate by a reduction in cell cycle time, as occurs after irradiation in the mouse. In the hyperproliferative mucosal state in the human small intestine found in coeliac disease, the cell production rate can be doubled by a halving of the cell cycle time. ${ }^{34}{ }^{38}$ This observation was also found in the colonic hyperplasia that accompanies carcinogen treatment in the rat. ${ }^{39}$ In contrast, cell production rate can be decreased by lengthening of the cell cycle time, as seen in starvation. $^{40-42}$

\section{THE GROWTH FRACTION}

The growth fraction in the gut proliferative system can be viewed from two different aspects. First, it can be viewed in terms of the whole crypt: in the slow cut off model of crypt cell proliferation, the position of the cut off zone is important in the control of proliferative compartment size. The cut off zone is where the daughter cells begin to decycle and differentiate, and thus its position controls the number of transit divisions in the system, and therefore the cell production rate of the 

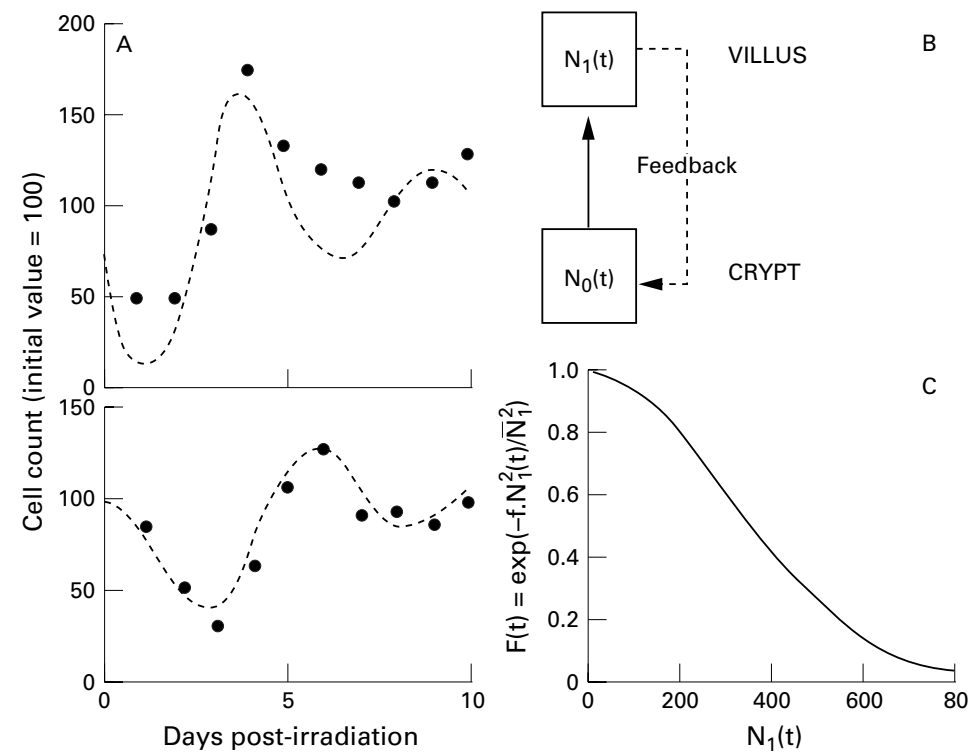

Figure 4 (A) Changes in the length of the crypt and villus in the mouse small intestine after 10 Gy of x irradiation. The broken line is fitted by simulation using the two compartment model shown in $(B)$, where negative feedback occurs from the villus epithelium to the crypt. (C) shows changes in the feedback function with changes in the size of the villus population (redrawn from Sato et al, ${ }^{35}$ ).

proliferative compartment. An upward extension of the proliferative compartment would thus increase the number of transit divisions and hence cell production. In many hyperproliferative states this is accompanied by other changes such as a reduction in cell cycle time, with or without an increase in crypt size, as in the intestinal mucosa during continuous irradiation, ${ }^{43}{ }^{44}$ or during administration of hydroxyurea, ${ }^{45}$ or in coeliac disease. ${ }^{33} 34$ The second way of looking at the growth fraction is in terms of the proliferative compartment itself. Although most people would argue that there are no $\mathrm{G}_{0}$ or resting cells in the proliferative compartment, in rats after prolonged starvation there is evidence that there are non-cycling cells in the proliferative compartment of the small intestine. After refeeding starved animals, there is an immediate increase in the size of the proliferative compartment, indicating these non-cycling cells reenter the cell cycle again. ${ }^{40} 46$

CHANGE IN THE CRYPT POPULATION (CRYPT SIZE) This is the most powerful method of increasing the cell production rate. An increase in the crypt population will increase the number of proliferating cells even though the growth faction is constant, as seen in animals in lactation, ${ }^{47}$ after intestinal resection, ${ }^{48}{ }^{49}$ and with continuous irradiation. ${ }^{42}{ }^{43}$ The growth fraction may actually be reduced, as in coeliac disease, but crypt cell production rate is increased by the massive increase in crypt size. The reason why population size changes are so potent in increasing the cell population rate compared with cell cycle time and growth fraction is because of the magnitude of changes possible. Well documented examples of increase in cell production rate caused by change in crypt population include partial intestinal resection and irradiation, while reductions in population size contribute to the decrease in crypt cell production rate, as seen in
starvation. ${ }^{41}{ }_{42}$

OTHER FACTORS

Some authorities consider control of proliferation can only act through the stem cell compartment, but the cell production rate is the consequence of the stem cell compartment efflux and the number of transit divisions. Doubling the number of transit divisions would produce twice the increment in cell production rate compared with doubling the stem cell output. Thus net movement of cut off position is a much more effective way of increasing the crypt cell production rate than increasing the stem cell efflux.

The net influx of cells into the functional compartment is the product of the cell production rate in the proliferative units and the number of units. Thus, net villus influx $=\mathrm{crypt}$ cell production rate $\times$ crypt:villus ratio. However, there is no evidence yet that adaptive changes such as starvation, resection, or lactation are associated with change in the crypt:villus ratio.

All the above mentioned factors or variables can change the crypt cell production rate, and they usually operate at the same time to produce net results.

\section{Control of intestinal cell proliferation}

There are three main hypotheses to account for the control of gastrointestinal epithelial cell proliferation. These are the local negative feedback from the structural to the reproductive compartments; the concept of luminal nutrition; and the effects of systemic factors.

NEGATIVE FEEDBACK CONTROL

There is considerable experimental evidence supporting a role for negative feedback in the gastrointestinal mucosae. ${ }^{50}$ Such a mechanism is especially important where tissue damage causes villus cell depletion. For example, a proliferative stimulus such as cytotoxic chemotherapy and whole body irradiation in mice will cause a series of oscillations of the crypt and villus populations in the mouse small intestine about the control values (fig 4 ) This strongly suggests that negative feedback control exists in the control of intestinal proliferation.

A very useful way of looking at the relations between crypt and villus populations was proposed by Cairnie et al in $1976^{51}$ : crypt cell population and the villus population were measured after cytotoxic chemotherapy. ${ }^{39} 45$ Then the villus population was plotted against the crypt population (fig 5A and 5B) The point of equilibrium is where the normal values for the villus population and the crypt population intersect, and the central shaded area is the maximum change in crypt population or villus population allowed before the point of no return-that is, tissue breakdown. In this scheme, any new steady state can be produced by shifting the equilibrium point to the right or left. The cytotoxic chemotherapy data are plotted in fig 5C. The initial flat trajectory describes crypt depopulation which occurs without villus depopulation, because of the 

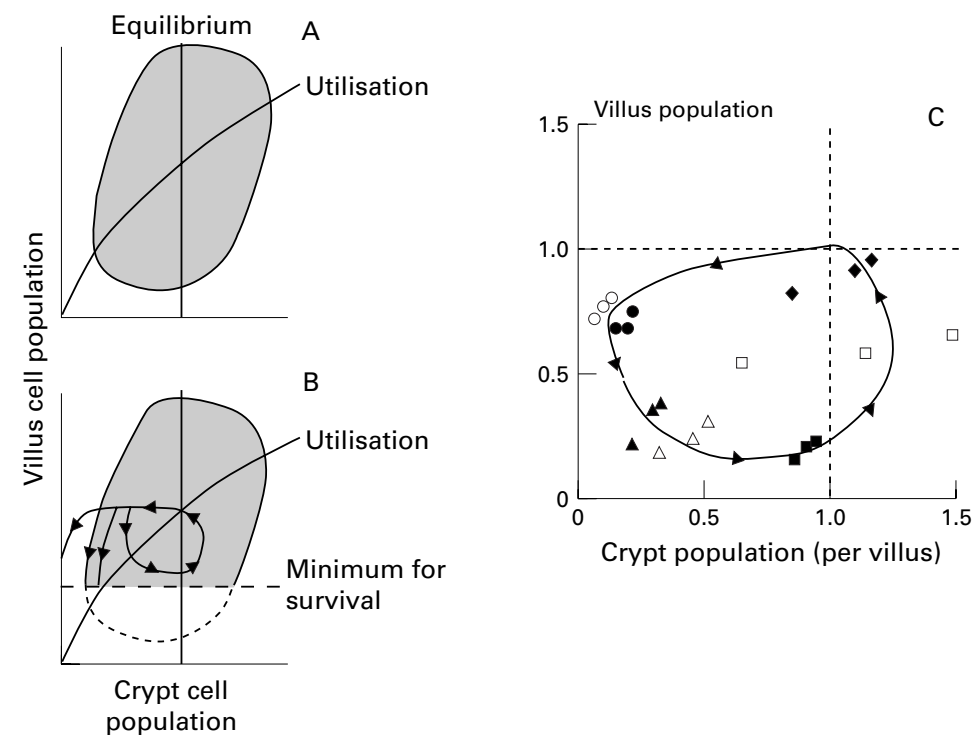

Figure 5 (A) The villus population plotted against the crypt population, where the shaded area indicates values for each where regeneration is still possible; $(B)$ the predicted response to different levels of irradiation) (redrawn from Cairnie ${ }^{51}$ ); (C) the villus population plotted against the crypt population after a schedule of injections of ara-C, for the first seven days after treatment (from Wright et al, ${ }^{50}$ with permission).

delay induced by the finite crypt to villus transit time. When the villus cell population begins to become depleted, this is indicated by a vertical downward trajectory, and note that this occurs without crypt repopulation; thereafter-possibly as a result of the lost of villus cells - there is an increase in the crypt cell production rate, and crypt repopulation occurs without villus repopulation (again because of the delay induced by crypt to villus transit time). The final return to the baseline is because of villus repopulation. This analysis indicates that crypt cell proliferation does not increase until villus cell population depletion has occurred. Together with the damped oscillations mentioned above, this strongly supports the operation of a negative feedback system.

\section{LUMINAL NUTRITION}

The presence of food in the bowel is mandatory for the maintenance of the functional cell mass. The concept of luminal nutrition ascribes the maintenance of appropriate morphology and cell replacement to the mucosal uptake of nutrients from the gut lumen. ${ }^{52}$ Conceptually, it is difficult to dissect this from the functional demand hypothesis, since the influence of food in the intestinal lumen will undoubtedly induce a functional demand on the intestine, in terms of the mucosal absorptive work that the mucosa must do, as well as providing luminal nutrition. In many experiments, it is impossible to distinguish between these two hypotheses. 3753

There is considerable evidence to support the importance of luminal nutrition: (1) the usual increase in cell production rate and villus height in the ileal remnant after partial small intestinal resection is profoundly reduced by isocaloric parental nutrition ${ }^{54}{ }^{55}$; (2) there is profound mucosal atrophy in animals during parenteral nutrition ${ }^{55-57}$; (3) jejunal bypass, in the form of a Thiry-Vella fistula, increases villus height and crypt cell production rate in the bowel in continuity, while the bypassed intestine shows hypoplasia with a decreased crypt cell production rate ${ }^{52} 55$; and (4) transposition of the ileal segments to the jejunum, where nutrients are in greater concentration, results in an increase in villus height and crypt cell production rate; jejunal-ileal transposition has the converse effect. ${ }^{55} 58$

From the growth control point of view, we need to distinguish between luminal nutrition and mucosal workload or functional demand. Perfusion experiments using glucose, galactose, and mannose provide evidence to support the functional demand or work load hypothesis. ${ }^{37} 53$ Furthermore, fibre-free elemental diets are associated with enteral atrophy, ${ }^{60}$ which is reduced by the addition of dietary fibre, but not by inert bulk. ${ }^{61}$ The magnitude of the trophic effect depends on the fermentability of the fibre, ${ }^{62}$ an effect of short chain fatty acids, which are the product of fibre fermentation by the microbiological flora. The response is abolished in the germ-free rat, confirming that it is products of the microbial fermentation of fibre, not fibre itself, that stimulate gastrointestinal proliferation. ${ }^{6364}$ Direct infusion studies of short chain fatty acids have confirmed this hypothesis. ${ }^{65} \mathrm{~A}$ second effect of fibre is to stimulate intestinal muscle mass, ${ }^{61}$ while a third effect is a direct, trophic effect on cell division in the stomach. ${ }^{66}$

Several other nutritional factors may also influence intestinal epithelial cell proliferation. Dietary calcium supplements decrease the colonic proliferation in rodents but human data are still inconclusive. ${ }^{67}{ }^{68}$ Omega-3 fish oils may also decrease colonic proliferation, perhaps by modulating prostaglandin synthesis. ${ }^{69}$ The modulation of prostaglandin synthesis in the colon may be protective against the development of cancer, as suggested by the beneficial effect of aspirin in the colon. ${ }^{70}$ Recently, lectins-which are carbohydrate binding proteins present in plants (particularly in seeds, young shoots, and bark, and in animal and human tissues, where they perform a variety of biological functions) - have been shown to affect colonic epithelial cell proliferation. For example, peanut lectin can increase rectal proliferation, while mushroom lectin has the opposite effect. ${ }^{71}$ The role of vitamins has also generated considerable interest. ${ }^{72}$

\section{SYSTEMIC FACTORS}

Gastrointestinal epithelial cell proliferation can be modulated by the local effects of hormones, peptides, and growth factors. Enteroglucagon, a 69 amino acid peptide, is part of a larger preproglucagon, which contains glicentin related pancreatic polypeptide (GRPP), glucagon, oxyntomodulin, and the glucagon-like peptides GLP1 and GLP2. GLP-2 has been shown to be a potent stimulant of intestinal epithelial proliferation. ${ }^{73-77}$ Gastrin is trophic to the fundic mucosa of the stomach. The introduction of proton pump inhibitors causes almost complete achlorhydria ${ }^{78}$ and in turn stimulates the hypersecretion of gastrin, which causes enterochromaffin-like (ECL) cell hyperplasia 
and even carcinoid formation in rodents. ${ }^{79-81}$ Besides the effect on gastric mucosa, gastrin was found to have a trophic effect to several colonic cell lines and carcinomas, ${ }^{82}$ and postprandial gastrin levels are higher in colon cancer patients. ${ }^{83}$

One of the most potent agents for stimulating gastrointestinal proliferation is epidermal growth factor (EGF). EGF is present in a variety of biological fluids, including milk, and stimulates proliferation and maturation of the pre- and postnatal intestine. ${ }^{84}$ It is a very potent timulator of epithelial cell production in the intestine of adult rats and humans. ${ }^{85} 86$ The proliferative effects in the rat are only seen when EGF is given systemically, ${ }^{87}$ and the lack of luminal effect may be because it is either broken down in the digesta ${ }^{88}$ or more likely due to its receptors being basolateral. ${ }^{89}$ Transforming growth factor alpha $(\mathrm{TGF} \alpha)$, which binds to the same receptor as EGF, ${ }^{90}$ also stimulates gastrointestinal epithelial cell proliferation but to a lesser extent. ${ }^{91} 92$

Trefoil peptides are small, secretory, stable peptides, bearing one or more trefoil structural motifs. ${ }^{93}$ They are produced rapidly at sites of injury and stimulate the repair process, particularly the early phase of epithelial restitution, possibly by inducing the migratory phenotype. In chronic ulcerative conditions such as Crohn's disease, trefoil peptides are secreted by a specific lineage called the ulcer associated cell lineage (UACL). ${ }^{94-96}$ Interestingly, these UACL glands also secrete EGF and $\mathrm{TGF} \alpha$, all potentially contributing to the healing process.

Prostaglandins can increase gastric cell proliferation and cell migration, ${ }^{97} 98$ and they stimulate proliferation in the small bowel but not in the colon..$^{99} 100$

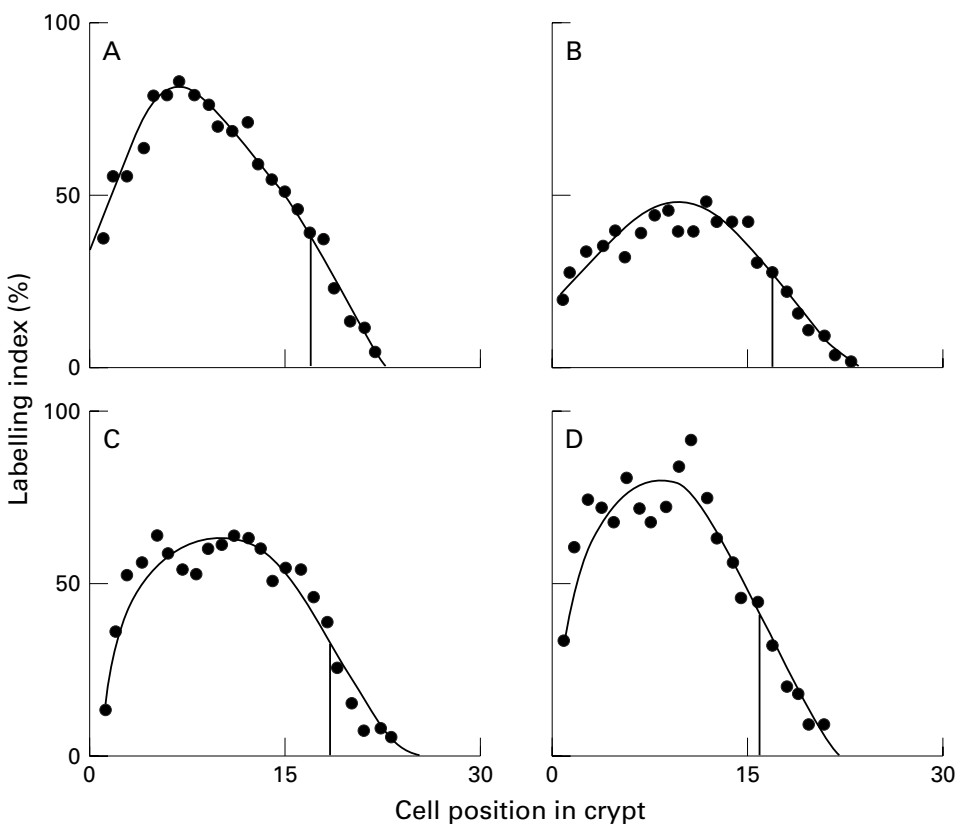

Figure 6 The effect of starvation and refeeding on the labelling index distribution curve in the rat: (A) at 4 hours after starvation; (B) after 96 hours starvation; (C) 8 hours after refeeding; (D) at 16 hours after refeeding. (From Al-Dewachi et al, ${ }^{46}$ with permission.)
Hypoproliferative states in the gastrointestinal mucosa

The best model of a hypoproliferative response in the gut is when the gut is deprived of exposure to luminal contents such as in starvation, and in certain surgical bypass procedures where the luminal stream is deflected. In starvation and bypass, there are significant morphological alterations in the form of atrophy; in the rat small intestine there is villus tip destruction, with basal fissuring and shortening of villi, implying a reduction in villus population. ${ }^{101}$ The reduction in villus population is indeed confirmed by morphometric and microdissection methods. ${ }^{102} 103$ There is also a reduction in the crypt cell population. ${ }^{104}$ Interestingly, the absolute number of crypts and villi remains unchanged in starvation, so that the crypt:villus ratio remains constant. ${ }^{105}$ The duration of the cell cycle is largely unchanged in rat during starvation. ${ }^{106}{ }^{107}$ But what happens to the distribution of labelled cells in the crypt? In the starved rat, there is no change in the size of the proliferative compartment, ${ }^{46}$ neither is there any apparent change in the distribution of labelled cells after small intestinal bypass. ${ }^{104}$ From the labelling index distribution curves, we can see that a substantial reduction in relative proliferative cellularity occurs, in addition to the absolute decrease due to the reduction in crypt size (fig 6). Thus the proliferative cellularity is almost halved, accounting for the $50 \%$ reduction in crypt cell production rate. Moreover, the peak labelling index is decreased in the starved animals, indicating the presence of resting or decycled cells in the proliferative compartment. ${ }^{40} 46$

Refeeding starved animals results in an increase in the labelling index, mitotic index, and crypt column length within hours in the rat jejunum. ${ }^{40}$ The villus population slowly recovers over about seven days in the rat. ${ }^{102}$

In conclusion, starvation clearly induces a hypoproliferative state in the whole gastrointestinal tract; in the small intestine there is also atrophy. The response to refeeding is very rapid in both the small intestine and the colon.

\section{Hyperproliferative states in the gastrointestinal mucosa}

The most striking growth response in the human small intestine is seen in coeliac disease. The characteristic histopathological features are a flat avillous duodeno-jejunal mucosa on stereomicroscopy, usually with a mosaic pattern, and with distinctive histological change: total villus atrophy, crypt hyperplasia, and a prominent infiltration of the lamina propria with plasma cells and lymphocytes. In this interesting condition, we have a mucosa which shows hyperplasia of one component only, the crypts, while the villi are effectively absent as discrete anatomical structures. Compared with normal controls, there is a large increase in the crypt column length and in the column count, indicating a threefold expansion of the crypt population. $^{33}{ }^{34}$ There is a significant increase in mitotic index, and inspection of mitotic index distribution curves suggests that the crypt growth fraction is decreased in the flat 
mucosa. Because of the expanded crypt population, there is also a threefold increase in the number of proliferative cells in the enlarged crypts. This would raise the crypt cell population by threefold. The number of cells in the maturation compartment is also increased.

By using the metaphase arrest ${ }^{34}$ and FLM method, ${ }^{38}$ the cell cycle time was shown to be halved in the flat mucosa ( 24 hours) compared with some 48 hours in controls. The doubling of crypt cell production rate by this change, coupled with the threefold increase produced by the expansion in the proliferative compartment, accounts for the fivefold increase in the crypt cell production rate. Interestingly, in the less severe form of the disease, in which the mucosal biopsy showed a large number of convolutions, ${ }^{108}$ there is a moderate increase in proliferative cellularity and a more modest decrease in the cell cycle time.

It appears that the initial event in the production of these abnormal mucosae is an increase in the surface cell loss rate. The degree of the cell loss determines the villus morphology, with minor levels resulting in convolutions, and severe injury resulting in the flat mucosa of coeliac disease. The crypt morphology is explained in terms of the cell kinetics, with large increases in the proliferative cellularity produced by crypt enlargement; also contributing to the cell production is a large reduction in cell cycle time.

Multifocal gastritis of the stomach caused by Helicobacter pylori may lead to development of atrophic gastritis, then to intestinal metaplasia, dysplasia, and finally to the development of gastric cancer. ${ }^{109}$ The whole spectrum of this pathology in the stomach is also hyperproliferative (see below).

In active ulcerative colitis, there is also a hyperproliferative state, and one result of this is that there is insufficient time for the daughter cells to differentiate, resulting in goblet cell depletion. ${ }^{110}$ There is no doubt that in patients with long standing ulcerative colitis, with the colon still in situ, the risk of colorectal carcinoma is increased. ${ }^{111}$ In active disease, the labelling index is increased, the turnover time is reduced, and the proliferative compartment expanded and moved upwards, as indicated by the position of the labelled cells in the crypt. ${ }^{112}$

\section{Cell proliferation in gastrointestinal carcinogenesis}

Most cells in the gastrointestinal epithelium have a limited life span, being extruded at the villus or colonic surface. The number of mutations required to provoke neoplastic change is still uncertain, but the age distribution of the incidence of gastrointestinal neoplasms suggests that this process lasts a significant time. The only cells which will remain in the crypt long enough to accumulate sequential mutations are the stem cells, as all other cells will be lost on the escalator. If a stem cell accumulates sufficient mutations to repopulate the crypts as a monocryptal adenoma, a crypt fission event which segregates the progeny of this stem cell into a daughter crypt will perforce mean that neoplastic stem cells will be present in the daughter crypt. Thus the stem cells are probably the targets for carcinogens to act upon.

In experimental animals, it is relatively easy to induce tumours in the stomach and colon, but quite difficult in the small intestine. This pattern is reproduced in human gut cancer. A possible reason for this singular distribution could be the difficulty of a transformed cell establishing a carcinogenic advantage in the rapidly proliferating small intestinal crypt, or the problems experienced by a crypt full of transformed stem cells recolonising an adjacent crypt by growing downwards against the prevailing current of cell migration. ${ }^{113}$

Much of our knowledge of cell proliferation during carcinogenesis in the gut comes from the use of experimental models. In the colon, the most valuable of these is the 1,2dimethylhydrazine (DMH) model. ${ }^{114}$ The incidence of colonic neoplasms is almost $100 \%$ in any dosage schedule. In the rat the neoplasms tend to be more isolated, whereas in the mouse they are widespread. ${ }^{115} \mathrm{~A}$ similar model is azoxymethane, also given subcutaneously on a weekly basis, which shows a similar distribution of lesions. In the experimental production of gastric cancer, the favoured agent has been N-methyl-N'-nitro-nitrosoguanidine (MNNG).

The acute effect of carcinogens on gastrointestinal epithelia is the inhibition of DNA synthesis. Histological examination shows prominent necrosis of the crypt cells in both large and small intestinal mucosae, extensive within six hours of treatment and recovering over the next 24 hours. ${ }^{116}$ The damage appears localised to the proliferative compartment of the crypt. This is followed by a prominent compensatory proliferative response, resulting in crypt hyperplasia. ${ }^{117}{ }^{118} \mathrm{~A}$ similar sequence of events has been described in the glandular stomach of the rat after application of acetomethyl-methylnitrosamine. ${ }^{119}$

Chronic treatment with suitable carcinogens (for example, weekly injection of DMH) leads to a variety of hyperplastic changes in gastrointestinal epithelia. It is widely considered that the dysplastic change, which eventually leads to invasive carcinoma, results directly from the hyperplastic mucosae. The hyperplasia during this phase is mediated by an increase in the crypt size, and is proportional to the duration of DMH treatment. ${ }^{115} 120$ The normal pattern of differentiation is preserved in these hyperplastic crypts, but there is an increased labelling index with upward shifting of labelled cells to the top of the crypt. Studies of the labelling index distribution curves indicate that the growth fraction is actually reduced in these crypts, but because of the increase in crypt size, there is either no change, or a small increase, in the absolute number of proliferating cells in the crypt. ${ }^{121}$ Analysis of the cell cycle in the rat DMH model showed that there was no change in cell cycle time in the small intestinal crypt but a general shortening of the cell cycle time in the colon, being more pronounced in the distal than the proximal colon. ${ }^{118}$ Thus in the colonic DMH model, there is a sustained 
hyperplasia during carcinogenesis, with a progressive reduction in the cell cycle time until, with the evolution of frankly neoplastic cells, the cell cycle time is decreased enough to confer a definite carcinogenic advantage.

So, if hyperplasia is considered important, what are the effects of hyperplasia itself upon carcinogenesis? Williamson had addressed this problem on a systematic basis, ${ }^{122}$ noting that the compensatory responses to manoeuvres such as small bowel resection were accompanied by hyperplastic changes in the colon; resected animals showed an increase in the prevalence of colonic tumours on DMH treatment. Interestingly, defunctioning of bowel segments showed a decrease in the incidence of colonic tumours in experimental animals treated with carcinogens. It thus appears that the initial proliferative status of the mucosa is an important variable in carcinogenesis in the colon.

In the human situation, in both the stomach and the colon there are well recognised premalignant lesions. These are characterised by increased proliferation rates, which are thought to be associated with a greater chance of developing carcinoma. In the stomach, this lesion is intestinal metaplasia, ${ }^{109}{ }^{123}$ with or without the association of chronic atrophic gastritis, while in the colon, chronic ulcerative colitis ${ }^{111}$ and benign adenomas of colon are associated with increased cancer risk. ${ }^{124-127}$

INTESTINAL METAPLASIA

In intestinal metaplasia the gastric mucosa undergoes a change to resemble that in the small intestine, complete with goblet and Paneth cells, though rarely with villi. In these intestinalised glands, labelled cells are confined to the lower portion, and there is a marked increase in proliferative activity, as evidenced by high in vitro labelling indices ${ }^{128} 129$ and Ki67 immunostaining. ${ }^{130} 131$ Some patients have expanded proliferative compartments, with DNA synthesis in surface cells, while in severe atrophic gastritis with intestinal metaplasia there is a reversion of the labelling index distribution curve to the format seen in the normal small bowel crypt. ${ }^{132}$ The birth rate in areas of intestinal metaplasia is two or three times the normal level. ${ }^{133}$ We can conclude that intestinal metaplasia is a hyperproliferative state.

Detailed study of he histogenesis of intestinal metaplasia showed that in early lesions, some glands have metaplastic features in their upper portion only, while the lower part of the gland remains occupied with normal pyloric cells; labelled cells are seen in the isthmus of these glands, and the Paneth cells appear just below this proliferative zone; thus the process begins in the original proliferative area of the gastric gland, through a change in the differentiation pattern of the gastric proliferating cells in this area. The proliferative zone then moves to the gland base, and the gland then fully resembles a small intestinal crypt. Intestinalisation is associated with the formation of cystic structures, which three dimensional analysis has shown to be completely separated from the gastric lumen, and to contain proliferating cells. Fujita and Hattori have suggested that the sequestration of transformed cells in these areas allows the evolution of neoplasia in spite of the continuous removal of cells in the general escalator. ${ }^{128}$ There is no doubt that dysplastic changes occur in areas of atrophic gastritis and intestinal metaplasia. ${ }^{109} 134135$ Increasing severity of dysplasia is associated with a progressively increasing cell population rate, with a resulting decrease in the turnover time and an expansion of the proliferative compartment, until in severe dysplasia all cells including surface cells appear proliferative. Invasive carcinoma may then evolve from this stage.

In the colon, patients with ulcerative colitis show evidence of an increased proliferative rate as described above. Thus intestinal metaplasia and ulcerative colitis are both lesions with raised proliferative rates, and hyperplasia itself is a promoter of gastrointestinal carcinogenesis, possibly acting through the abolition of genetic housekeeping in gastrointestinal stem cells, and the hyperplasia itself may be responsible for the association with increased cancer incidence. However, apart from de novo cancers that develop in ulcerative colitis, most malignant colonic tumours develop from a non-invasive adenoma. By in vitro labelling studies and PCNA and Ki67 immunostaining labelling indices, it is generally claimed that there is progression in the proliferative rate from normal mucosa to adenoma and then to carcinoma. ${ }^{136-140}$ In the well established model described by Fearon and Vogelstein there are progressive genetic changes during the progression of adenoma to carcinoma in situ to invasive carcinoma. ${ }^{141}$ It appears that this hyperproliferative state-a progressive accumulation of a series of somatic mutations in the stem cells, which have a long residence time in the mucosa-will eventually lead to the development of the malignant phenotype, possessing some growth advantage over other stem cells within the crypt or gland. Alternatively, an initial mutation, such as one leading to loss of heterozygosity of the APC gene in a colonic epithelial cell, then spreads through the crypt merely by a stochastic process in which the crypt becomes occupied by a monoclonal population of such cells. This monoclonal conversion event has been documented in animals injected with mutagens, and following the development of mutated clones in the colonic crypts, by using gene products such as glucose6-phosphate dehydrogenase (G6PD) or the binding of DBA. ${ }^{8} 9$ Once the mutated clone is established, it is proposed that this spread occurs by a process of crypt fission, in which the crypt divides into two, and thus the mutated clone spreads through the mucosa ${ }^{9}$ (fig 7) There is also documented human evidence that large areas of colonic mucosa are colonised by dysplastic crypts containing a single aneuploid stem line. Moreover, the predominant mode of growth of adenomas is also by fission of the adenomatous crypts. ${ }^{142}$ Interestingly, in FAP colon, detailed microdissection studies show that the major abnormality observed is an increased crypt fission index and not an increase in crypt epithelial cell 

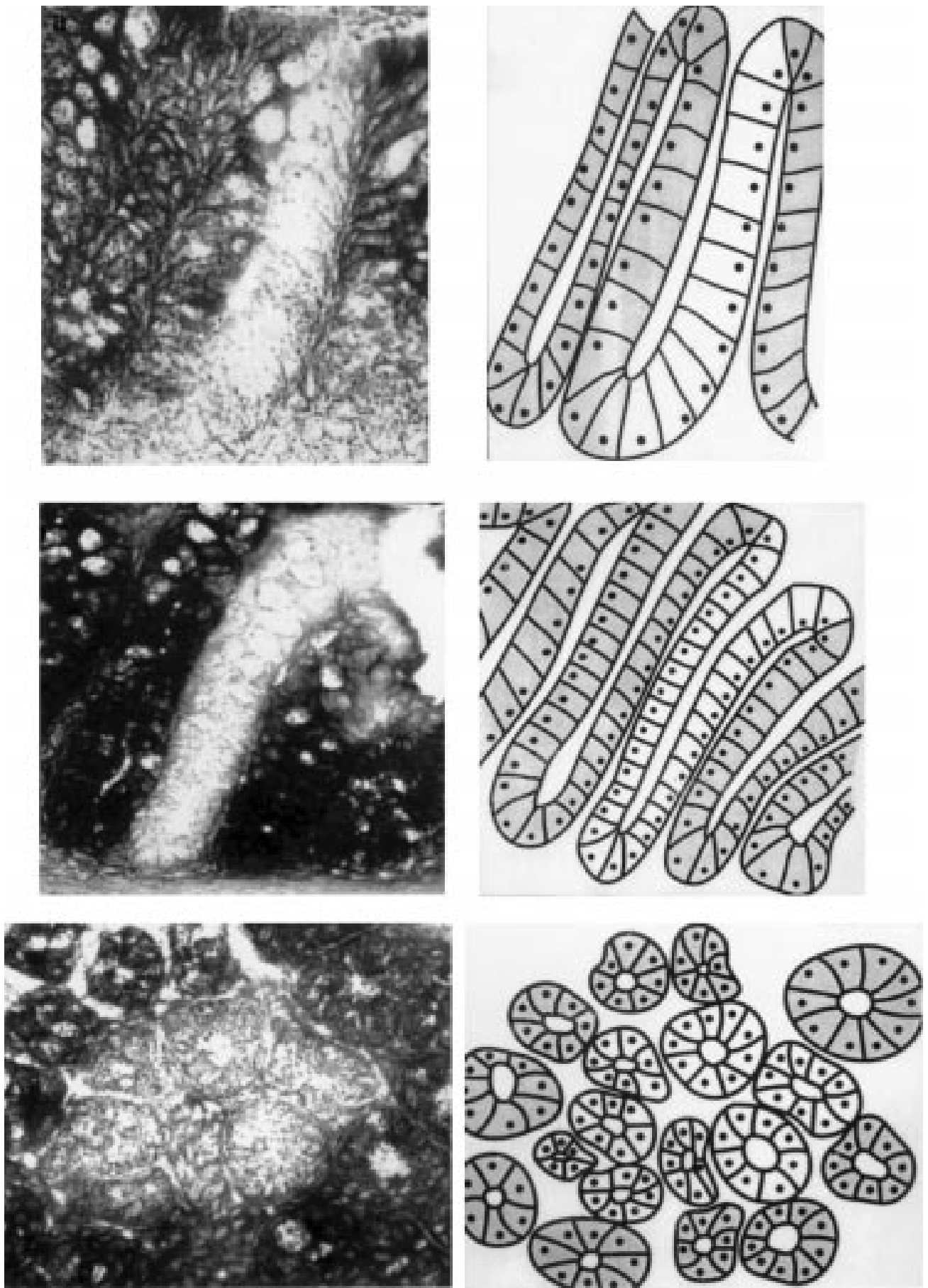

Figure 7 Top panel: a section of mouse colon stained for the presence of glucose-6-phosphate dehydrogenase (G6PD) after treatment with ethyl nitrosourea; only the right hand hemi-crypt has lost staining for the enzyme, but in the middle panel the entire crypt is converted to a population of cells which are negative for G6PD; the bottom panel shows a patch of mutated crypts, negative for G6PD, which has grown by crypt fission. (From Park et al, ${ }^{9}$ with permission.)

proliferation rate. There is also no difference between FAP colonic mucosa and the controls in the distribution of mitotic figures. Furthermore, a recent study by Jass and colleagues has shown that there is no difference in Ki67 labelling index between patients with hereditary non-polyposis colorectal cancer and subjects with some positive family history of colorectal cancer. ${ }^{143}$ Thus it appears that hyperproliferation is not a general phenomenon in the early step of colonic carcinogenesis, and Jass et al consider that it is unlikely that hyperproliferation plays any part in the pathogenesis of com- mon colorectal cancers. Crypt fission may play an important role in these early events, both for the spread of the neoplastic clones and the growth of the adenomas.

There is as yet no evidence that the same process occurs in the gastric gland. But it would be reasonable to propose that a mutation in stem cells situated at the neck would spread through the gastric gland in a similar manner to that described in the colon. Furthermore, it is known that gastric glands reproduce by a process of gland fission, in which the initial budding event takes place at 
the neck, where the stem cells are located. ${ }^{128}$ Thus, once a gastric gland is colonised by mutated cells, the gland will spread through the mucosa by gland fission, and it is likely that field cancerisation in gastrointestinal epithelia is caused by mutated clones spreading in this manner. ${ }^{144}$

\section{Conclusion}

We have come a long way in the study of proliferation of gastrointestinal mucosa, from the study of the kinetic behaviour, proliferation in different physiological and pathological conditions, to the study of the stem cell repertoire which lead us to understand and speculate on the underlying mechanism of a host of interesting conditions in the gastrointestinal tract. Perhaps in the future, the study of this elusive stem cell will give us information concerning the ultimate control of proliferation and about carcinogenic mechanisms, and will lead to successful and stable gene transfer in the gastrointestinal mucosa.

This work was supported by the Imperial Cancer Research Fund and Croucher Foundation Fellowship to WMW, who is presently affiliated to the Department of Medicine, Queen Mary presently affiliated to the Department
Hospital, University of Hong Kong.

1 Smith JA. The cell cycle and related concepts in cell proliferation. F Pathol 1982;136:149-66.

2 Hauft SM, Kim SH, Schmidt GH, et al. Expression of SV-40 T-antigen in the small intestinal epithelium of transSV-40 T-antigen in the small intestinal epithelium of trans-
genic mice results in proliferative changes in the crypt and genic mice results in proliferative changes in the crypt and
re-entry of villus-associated enterocytes into the cell-cycle re-entry of villus-associated enterocytes into the cell-cycle
but has no apparent effect on cellular-differentiation but has no apparent effect on cellular-differentiation
programs and does not cause neoplastic transformation. $\mathcal{F}$ programs and does not cause
Cell Biol 1992;117:825-39.

3 Hargest R, Williamson R. Expression of the APC gene after transfection into a colonic cancer cell line. Gut 1995;37: $826-9$

4 Hendry JH, Roberts SA, Potten CS. The clonogen content of murine intestinal crypts: dependence on radiation dose used in its determination. Radiat Res 1992;132:115-19.

5 Kirkland SC. Clonal origin of columnar, mucous and endocrine cell lineages in human colorectal epithelium. Cancer 1988;61:1359-63.

6 Ponder BA, Schmidt GH, Wilkinson MM, et al. Derivation of mouse intestinal crypts from a single progenitor cells.

7 Schmidt G, Winton DJ, Ponder BA. Development of the pattern of cell renewal in the crypt-villus unit of the
chimaeric mouse small intestine. Development 1988;103: 785-90.

8 Williams ED, Lowes AP, Williams D, et al. A stem cell niche theory of intestinal crypt maintenance based on a study of somatic mutation in colonic mucosa. Am $f$ Pathol 1992;141:773-6.

9 Park HS, Goodlad RA, Wright NA. Crypt fission in the small intestine and colon. A mechanism for the emergence of G6PD locus-mutated crypts after treatment with mutagens. Am f Pathol 1995;147:1416-27.

10 Thompson M, Fleming KA, Evans DJ, et al. Gastric endocrine cells share a clonal origin with other gut cell lineages. Development 1990;110:477-81.

11 Tatematsu M, Fukami H, Yamamoto M, et al. Clonal analysis of glandular stomach carcinogenesis in $\mathrm{C} 3 \mathrm{~h} / \mathrm{HeN}<-$ $>$ Balb/c chimaeric mice treated with N-methyl-Nnitrosurea. Cancer Lett 1994;83:37-42.

12 Novelli MR, Williamson JA, Tomlinson IPM, et al. Polyclonal origin of colonic adenomas in an $\mathrm{XO} / \mathrm{XY}$ patient with nal origin of colonic adenomas in
FAP. Science 1996;272:1187-90.

13 Dover R. Basic methods for assessing cellular proliferation. In: Hall PA, Levison DA, Wright NA, eds. Assessment of proliferation in clinical practice, 1 st ed. London: SpringerVerlag, 1992:63-81

14 Beck HP. Radiotoxicity of incorporated $[3 \mathrm{H}]$ thymidine. Consequences for the interpretation of FLM data of irradiated cell populations. Cell Tiss Kinet 1982;15:469-72

15 Post J, Hoffman J. Early and late effects of 3H-TdR-labelled DNA on ileal cell replication in vivo. Radiat Res 1968;34:570-82.

16 Hume WJ, Potten CS. A long-lived thymidine pool in epithelial stem cells. Cell Tissue Kinet 1982;15:49-58.

17 Goodlad RA, Wright NA. Quantitative studies on epithelial replacement in the gut. In: Titchen TA, ed. Techniques in the life sciences: techniques in digestive physiology, vol P2. Dublin: life sciences: techniques in digestive physiology, vol
Elsevier Biomedical Press, 1982:212/1-212/21

18 Wanders SL, ten Kate J, van der Linden E, et al. Does ex vivo labelling of proliferating cells in colonic and vaginal mucosa reflect the S-phase fraction in vivo? Histochemistry 1992;98:267-70.
19 Bravo R, Frank R, Blundell PA, et al. Cyclin/PCNA is the auxiliary protein of DNA polymerase-delta. Nature 1987; 326:515-17.

20 Prelich G, Tan CK, Kostura M, et al. Functional identity of proliferating cell nuclear antigen and a DNA polymerase-delta auxiliary protein. Nature 1987;326: $517-20$

21 Fairman MP. DNA polymerase delta/PCNA: actions and interactions. F Cell Sci 1990;95:1-4.

22 Hall PA, Levison DA, Woods AL, et al. Proliferating cell nuclear antigen (PCNA) immunolocalisation in paraffin sections: an index of cell proliferation with evidence of deregulation in some neoplasms. F Pathol 1990;162:285-

Yu CCW, Woods AL, Levison DA. The application of immunohistochemistry in assessment of cellular proliferation. In: Hall PA, Levison DA, Wright NA, eds. Assessment of proliferation in clinical practice, 1 st ed. London: Springer-

24 Scott RJ, Hall PA, Haldane JS, et al. A comparison of immunohistochemical markers of cell proliferation with experimentally determined growth fraction. F Pathol 1991; 165:173-8.

25 Gerdes J, Lemke H, Baisch H, et al. Cell cycle analysis of a cell proliferation-associated human nuclear antigen defined by the monoclonal antibody Ki67. F Immunol 1984;133: $1710-15$.

26 Gerdes J, Li L, Schlüter C, et al. Immunobiochemical and molecular biologic characterization of the cell proliferationassociated nuclear antigen that is defined by monoclonal associated ni67. Am f Pathol 1991;138:867-73.

27 McCormick D, Chong H, Hobbs C, et al. Detection of the Ki67 antigen in fixed and wax embedded sections with the monoclonal antibody MIB1. Histopathology 1993;22:35560

28 Key G, Becker MH, Baron B, et al. New Ki-67-equivalent murine monoclonal antibodies (MIB 1-3) generated against bacterially expressed parts of the Ki67 cDNA containing three 62 base pair repetitive elements encoding for the Ki-67 epitope. Lab Invest 1993;68:629-36.

29 Gerlach C, Golding M, Laure L, et al. Ki67 immunoexpression is a robust marker of proliferative cells in the rat. Lab Invest 1997;77:697-8.

30 Goodlad RA, Wright NA. Epithelial kinetics; control and consequences of alteration in disease. In: Whitehead, ed. Gastrointestinal and oesophageal pathology, 2nd ed. Edinburgh: Churchill Livingstone, 1995:97-115.

31 Goodlad RA, Levi S, Lee CY, et al. Morphometry and cell proliferation in endoscopic biopsies: evaluation of a technique. Gastroenterology 1991;101:1235-41

32 Savidge TC, Walker-Smith JA, Phillips AD. Novel insights into human intestinal epithelial cell proliferation in health and disease using confocal microscopy. Gut 1995;36:369-

33 Wright NA, Watson A, Morley A, et al. Cell kinetics in flat avillous) mucosa of the human small intestine. Gut 1973; 14:701-10.

34 Wright NA, Watson A, Morley A, et al. The cell cycle time in the flat (avillous) mucosa of the human small intestine. Gut 1973;14:603-6.

35 Sato F, Muramatsu S, Tsuchihashi S, et al. Radiation effects on cell populations in the intestinal epithelium of mice and its theory. Cell Tissue Kinet 1972;5:227-35.

36 Cairnie AB, Lamerton LF, Steel GG. Cell proliferation studies in intestinal epithelium of the rat. II. Theoretical aspects. Exp Cell Res 1965;39:539-53.

37 Clarke RM. Intestinal function and epithelial replacement. Cambridge: University of Cambridge, 1975 [MD thesis].

38 Weinstein WM, Tytgat GN, Chen M, et al. In vivo studies of cell proliferation and kinetics in the human jejunal mucosa. Gastroenterology 1973;64:A137/820.

39 Al-Dewachi HS, Wright NA, Appleton DR, et al. The effect of a single injection of cytosine arabinoside on cell population kinetics in the mouse jejunal crypt. Virchows Arch B Cell Pathol Mol Pathol 1980;34:299-309.

40 Hagemann RF, Stragand JJ. Fasting and refeeding: cell kinetic response of jejunum, ileum and colon. Cell Tissue Kinet 1977;10:3-14

41 Hooper AF, Wannemacher RW, McGovern PA. Cell population changes in the intestinal epithelium of the rat following starvation and protein-depletion. Proc Soc Exp Biol Med 1968;128:695-8.

42 Hooper AF, Rose PM, Wannemacher RW. Cell population changes in the intestinal mucosa of protein-depleted or starved rats. II. 7 Cell Biol 1972;53:225-30.

43 Cairnie AB. Cell proliferation studies in the intestinal epithelium of the rat: response to continuous irradiation. Radiat Res 1967;32:240-64.

44 Rijke RP, Plaisier H, Hoogeveen AT, et al. The effect of continuous irradiation on cell proliferation and maturation in small intestinal epithelium. Cell Tissue Kinet 1975;8:44153.

45 Al-Dewachi HS, Wright NA, Appleton DR, et al. The effects of a single injection of hydroxyurea on cell population kinetics in the small bowel mucosa of the rat. Cell Tissue Kinet 1977;10:203-13.

46 Al-Dewachi HS, Wright NA, Appleton DR, et al. The effect of starvation and refeeding on cell population kinetics in the rat small bowel mucosa. F Anat 1975;119: 105-21

47 Cairnie AB, Bentley RE. Cell proliferation studies in the intestinal epithelium of the rat. Hyperplasia during lactation. Exp Cell Res 1967;46:428-40. 
48 Hanson WR, Osborne JW, Sharp JG. Compensation by the residual intestine after intestinal resection in the rat. residual intestine after intestinal resection in the rat. I Influence of amo

49 Hanson WR, Osborne JW, Sharp JG. Compensation by the residual intestine after intestinal resection in the rat. II. Influence of the post-operative time interval. Gastroenterology 1977;72:701-5.

50 Wright NA, Alison MR. The biology of epithelial cell populations, vol 2. Oxford: Oxford University Press, 1984.

51 Cairnie AB. Homeostasis in the small intestine. In: Cairnie AB, Lala PK, Osmond DG, eds. Stem cells of renewing cell
populations. New York: Academic Press, 1976:67-78.

52 Gleeson MH, Dowling RH, Peters TJ. Biochemical changes in intestinal mucosa after experimental by-pass in the rat. in intestinal mucosa after

53 Clarke RM. "Luminal nutrition" versus "functional workload" as controllers of mucosal morphology and epithelia replacement in the rat small intestine. Digestion 1977;15 411-24.

54 Feldman EJ, Dowling RH, McNaughton J, et al. Effect of oral versus intravenous nutrition on intestinal adaptation after small bowel resection in the dog. Gastroenterology 1976;70:712-19.

55 Al-Mukhtar MYT, Sagor GR, Ghatei MA, et al. The relationship between endogenous gastrointestinal hormones and cell proliferation in models of intestinal adaptation. In: Robinson JWL, Dowling HR, Riecken EO, eds. Mechanisms of intestinal adaptation. Lancaster: MTP Press, 1982:243-53.

56 Hughes CA, Bates T, Dowling RH. Cholecystokinin and secretin prevent the intestinal mucosal hypoplasia of total parental nutrition in the dog. Gastroenterology 1978;75:34 41.

57 Hughes CA, Breuer RS, Ducker DA, et al. The effect of cholecystokinin and secretin on pancreatic structure and function. In: Robinson JWL, Dowling HR, Riecken EO, eds. Mechanisms of intestinal adaptation. Lancaster: MTP Press, 1982:435-50

58 Dowling RH, Booth CC. Structural and functional changes following small intestinal resection in the rat. Clin Sci 1967; 32:139-49.

59 Wright NA, Morley A, Appleton DR. Variation in the duration of mitosis in the crypts of Lieberkuhn of the rat: a tion of mitosis in the crypts of Lieberkuhn of the rat: a 1972;5:351-64.

60 Janne P, Carpentier Y, Willems G. Colonic mucosal atrophy induced by a liquid elemental iet in rats. Am f Dig Dis 1977;22:808-12

61 Goodlad RA, Wright NA. The effects of addition of kaolin or cellulose to an elemental diet on intestinal cell proliferation in the mouse. Br F Nutr 1983;50:91-9.

62 Goodlad RA, Lenton W, Ghatei MA, et al. Effects of an elemental diet, inert bulk and different types of dietary fibre on the response of the intestinal epithelium to refeeding in the rat and relationship to plasma gastrin, enteroglucagon, and PYY concentrations. Gut 1987;28:171-80.

63 Sakata T, Yajima T. Influence of short chain fatty acids on the epithelial cell division of digestive tracts. $Q \mathcal{F}$ Exp Physio 1984;69:639-48.

64 Goodlad RA, Ratcliffe BR, Fordham JP, et al. Does dietary fibre stimulate intestinal epithelial cell proliferation in germ free rats? Gut 1989;30:820-5.

65 Kripke SA, Fox AD, Berman JM, et al. Stimulation of intestinal mucosal growth with intracolonic infusion of shortchain fatty acids. F Parenter Enter Nutr 1989;13:109-16.

66 Goodlad RA, Ratcliffe B, Lee CY, et al. Dietary fibre and the gastrointestinal epithelium: differential response in the stomach, small intestine and colon of conventional and germ-free rats. In: Waldron KW, Johnson IT, Fenwick GR, eds. Food and cancer prevention: chemical and biological aspects. Cambridge: Royal Society of Chemistry, 1993: 364-8.

67 Beaty MM, Lee EY, Glauert HP. Influence of dietary calcium and vitamin D on colon epithelial cell proliferation in rats fed high fat diets. 7 Nutr 1993;123:144-52.

68 Bostick RM, Potter JD, Fosdick L, et al. Calcium and colorectal epithelial cell proliferation $Ð$ a preliminary randomized, double-blind, placebo-controlled clinical trial. $\mathcal{F}$ Natl Cancer Inst 1993;85:132-41.

69 Wargovich MJ. Fish oils and cancer. Gastroenterology 1992;103:1096-8.

70 Thun MJ, Namboodiri MM, Heath CW. Aspirin use and reduced risk of fatal colonic cancer. $N$ Engl $7 \mathrm{Med}$ 1991;325:1593-6.

71 Ryder SD, Jacyna MR, Levi J, et al. Peanut ingestion increases rectal proliferation in individuals with mucosal expression of peanut lectin receptor. Gastroenterology 1998; 114:44-9.

72 Newmark HL, Lipkin M. Calcium, vitamin D, and colon cancer. Cancer Res 1992;52:2067-70s.

73 Tsai CH, Hill M, Drucker DJ. Biological determinants of intestinotrophic properties of GLP-2 in vivo. Am f Physio 1997;272:G662-8.

74 Brubaker PL, Izzo A, Hill M, et al. Intestinal function in mice with small bowel growth induced by glucagon-like peptide-2. Am f Physiol 1997;272:E1050-8.

75 Tsai CH, Hill M, Asa SL, et al. Intestinal growth-promoting properties of glucagon-like peptide-2 in mice. Am F Physiol 1997;273:E77-84.

76 Dunphy JL, Fuller PJ. Enteroglucagon, bowel growth and GLP-2. Mol Cell Endocrinol 1997;132:7-11.
77 Drucker DJ, DeForest L, Brubaker PL. Intestinal response to growth factors administered alone or in combination with human [Gly2] glucagon-like peptide 2. Am f Physiol 997:273:G1252-62.

78 Fave GD, Helander H, Holt S, et al. Acid suppression and gastric mucosal cell biology. Dig Dis Sci 1995;40:121-31S.

79 Tielemans Y, Hakanson R, Sundler F, et al. Proliferation of enterochromaffinlike cells in omeprazole-treated hypergastrinaemic rats. Gastroenterology 1989;96:723-9.

80 Eissele R, Rosskopf B, Koop H, et al. Proliferation of endocrine cells in the rat stomach caused by drug-induced achlorhydria. Gastroenterology 1991;101:70-6.

81 Havu N. Enterochromaffin-like cell carcinoids of gastric mucosa in rats after life-long inhibition of gastric secretion. Digestion 1986;35:42-55.

82 Eggstein S, Imdahl A, Kohler M, et al. Influence of gastrin, gastrin receptor blockers, epidermal growth factor, and difluoromethylornithine on the growth and the activity of ornithine decarboxylase of colonic carcinoma cells. f Cancer Res Clin Oncol 1991;117:37-42.

83 Wong K, Beardshall K, Waters CM, et al. Postprandial hypergastrinaemia in patients with colorectal cancer. Gut 1991;32:1352-4.

84 Weaver LT, Walker WA. Epidermal growth factor and the developing human gut. Gastroenterology 1988;94:845-7.

85 Sullivan PB, Brueton MJ, Tabara ZB, et al. Epidermal growth factor in necrotising enteritis. Lancet 1991;338:534 .

86 Walker-Smith JA, Phillips AD, Walford N, et al. Intravenous epidermal growth factor / urogastrone increases smallintestinal cell proliferation in congenital microvillous atrophy. Lancet 1985 ;ii: $1239-40$.

87 Goodlad RA, Wilson TJ, Lenton W, et al. Intravenous but not intragastric urogastrone-EGF is trophic to the intestinal epithelium of parenterally fed rats. Gut 1987;28: $573-82$

88 Playford RJ, Woodman AC, Clark P, et al. Effect of luminal growth factor preservation on intestinal growth. Lancet 1993;341:843-8

89 Scheving LA, Shiurba RA, Nguyen TD, et al. Epidermal growth factor receptor of the intestinal enterocyte. Localization to laterobasal but not brush border membrane. $\mathcal{f}$ Biol Chem 1989;264:1735-41.

90 Burgess AW. Epidermal growth factor and transforming growth factor alpha. Br Med Bull 1989;45:401-24.

91 Goodlad RA, Lee CY, Wright NA. TGF-alpha and intestinal epithelial cell proliferation in parenterally fed rats [abstract]. Gut 1990;31:A1197.

92 Sandgren EP, Luetteke NC, Palmiter RD, et al. Overexpression of TGF alpha in transgenic mice: induction of epithelial hyperplasia, pancreatic metaplasia and carcinoma of the breast. Cell 1990;61:1121-35.

93 Poulsom R. Trefoil peptides. Baillieres Clin Gastroenterol 1996;10.1:113-34

94 Wright NA, Pike C, Elia G. Induction of a novel epidermal growth factor-secreting cell lineage by mucosal ulceration in human gastrointestinal stem cells. Nature 1990;343:825 .

95 Wright NA, Poulsom R, Stamp G, et al. Trefoil gene expression in gastrointestinal epithelial cells in inflammatory bowel disease. Gastroenterology 1993;104:12-20.

96 Poulsom R, Chinery R, Sarraf C, et al. Trefoil peptide gene expression in intestinal adaptation and renewal. Scand $\mathcal{F}$ Gastroenterol 1992;192(suppl): 17-28.

97 Goodlad RA, Madgwick AJ, Moffatt MR, et al. Prostaglandins and gastric epithelium: effects of misoprostal on gastric epithelial cell proliferation in the dog. Gut 1989;30: 316-21.

98 Goodlad RA, Madgwick AJ, Moffatt MR, et al. Effects of misoprostal on cell migration and transit in the dog stomach. Gastroenterology 1990;98:90-5.

99 Goodlad RA, Lee CY, Levin S, et al. Effects of the prostaglandin analogue misoprostal on cell proliferation in prostaglandin analogue misoprostal on cell proliferation

100 Goodlad RA, Mandir N, Levin S, et al. Prostaglandins and the colonic epithelium: effects of misoprostal on crypt size, cell production, and cell migration in the dog. Gastroenterology 1991;101:1229-34

101 Brown HO, Levine ML, Lipkin M. Inhibition of intestinal cell renewal and migration induced by starvation. $A m$ f Physiol 1963;205:868-72.

102 Altmann GG. Influence of starvation and refeeding on mucosal size and epithelial renewal in the rat small intestine. Am f Anat 1972;133:391-400.

103 Goodlad RA, Wright NA. The effects of starvation and refeeding on intestinal cell proliferation in the mouse. Virchows Arch B Cell Pathol Mol Pathol 1984;45:63-73.

104 Rijke RP, Plaisier H, de Ruiter H, et al. Influence of experimental bypass on cellular kinetics and maturation of small intestinal epithelium in the rat. Gastroenterology 1977;72: 896-901.

105 Clarke RM. The effect of growth and of fasting on the number of villi and crypts in the small intestine of the albino rat. F Anat 1972;112:27-33.

106 Rose PM, Hopper AF, Wannemacher RW. Cell population changes in the intestinal mucosa of protein depleted or starved rats. I. Changes in mitotic cycle time. $\mathcal{f}$ Cell Biol 1971;50:887-92.

107 Wright NA. The cell population kinetics of repopulating cells in the intestine. In: Lord BI, Potten CS, Cole RJ, eds. Stem cells and tissue homeostasis. Cambridge: Cambridge University Press, 1978:335-58. 
108 Wright NA, Appleton DR, Marks J, et al. Cytokinetic studies of crypts in convoluted human small-intestinal mucosa. 7 Clin Pathol 1979;32:462-70.

109 Correa P. A human model for gastric carcinogenesis. Cancer Res 1988;48:3554-60.

110 Sommers SC, Korelitz BI. Mucosal-cell counts in ulcerative and granulomatous colitis. Am f Clin Pathol 1975;63:359-65

111 Levin B. Ulcerative-colitis and colon cancer: biology and surveillance. F Cell Biochem 1992;16G(suppl): $47-50$

112 Bleiberg H, Mainguet P, Galand P, et al. Cell renewal in the human rectum: in vitro autoradiographic study on active ulcerative colitis. Gastroenterology 1970;58:851-5.

113 Cairns J. Mutation, selection and the natural history of cancer. Nature 1975;225:197-200.

114 Druckrey H, Preussmann R, Matzkies F, et al. Selektive erzengung von Darmkerbs bei Ratten durch 1.2 Dimethylhydrazin. Naturwissenschaften 1967;54:285-6.

115 Chang WWL. Pathogenesis and biological behaviour of 1.2-dimethylhydrazine-induced colonic neoplasms in the
mouse. In: Appleton DR, Sunter JP, Watson AJ, eds. Cell mouse. In: Appleton DR, Sunter JP, Watson AJ, eds. Cell proliferation in the gast

116 Zedeck MS, Grab DJ, Sternberg SS. Differences in the acute response of the various segments of rat intestine to treatment with the intestinal carcinogen methylazoxymethanol acetate. Cancer Res 1977;37:32-6.

117 Deschner EE. Early proliferative effects induced by six weekly injections of 1,2-dimethylhydrazine in epithelia cells of mouse distal colon. Z Krebsforsch Klin Onkol Cance Res Clin Oncol 1978;91:205-16.

118 Sunter JP. Cell proliferation studies on normal, carcinogenicdamaged and neoplastic int Tyne: University of Newcastle upon Tyne, 1981 [MD theTyne:
sis].

119 Schmahl P. Carcinogenic substances and carcinogenesistheir chemical significance. In: Herfarth $\mathrm{Ch}$, Schlag P, eds. Gastric cancer. Berlin: Springer, 1979:15-19.

120 Chang WWL. Histogenesis of symmetrical 1.2 dimethylhydrazine-induced neoplasms of the colon in the dimethylhydrazine-induced neoplasms of the

121 Maskens AP. Histogenesis and growth pattern of 1,2dimethylhydrazine-induced rat colon adenocarcinoma. Cancer Res 1976;36:1585-92.

122 Williamson RC. Hyperplasia and neoplasia of the intestinal tract. Ann R Coll Surg Engl 1979;61;341-8.

23 Stemmermann GN. Intestinal metaplasia of the stomach. A status report Cancer 1994;74:556-64

124 Muto T, Bussey HJ, Morson BC. The evolution of cancer of the colon and rectum. Cancer 1975;36:2251-70.

125 Eide TJ. Risk of colorectal cancer in adenoma-bearing individuals within a defined population. Int f Cancer 1986, 38:173-6.

126 Winawer SJ, O'Brien MJ, Waye JD, et al. Risk and surveillance of individuals with colorectal polyps. Who Collaborating Centre for the Prevention of Colorectal Cancer. Bull WHO 1990;68:789-95.

127 Winawer SJ, Zauber AG, Ho MN, et al. Prevention of colorectal cancer by colonoscopic polypectomy. The National Polyp Study Workgroup. N Engl fु Med 1993;329: $1977-81$
128 Fujiti S, Hattori T. Cell proliferation, differentiation and migration in the gastric mucosa; a study of the background of carcinogenesis. In: Farber E, Sigano H, eds. Pathophysiology of carcinogenesis in digestive organs. Baltimore: University Park Press, 1977:22-31. 129 Lynch DA, Mapstone NP, Clarke AM, et al. Cell prolifera-
tion in Helicobacter pylori associated gastritis and the effect of eradication therapy. Gut 1995;36:346-50.

130 Imatani A, Sasano H, Yabuki N, et al. In situ analysis of tissue dynamics and p53 expression in human gastric mucosa. F Pathol 1996;179:39-42.

131 Yabuki N, Sasano H, Tobita M, et al. Analysis of cell damage and proliferation in Helicobacter pylori-infected cinoma. Am f Pathol 1997;151:821-9.

132 Deschner EE, Lipkin N. Proliferation and differentiation of gastrointestinal cells in health and disease. In: Lipkin M, Good R, eds. Gastrointestinal tract cancer. New York: Plenum, 1978:3-27.

133 Wright NA, Britton DR, Bone G, et al. An in vivo stathmokinetic study of cell proliferation in human gastric carcinoma and gastric mucosa. Cell Tissue Kinet 1977;10: 429-36.

134 Cuello C, Correa P. Dysplastic changes in intestinal metaplasia of gastric mucosa. In: Herfarth C, Schlag P, eds. Gastric cancer. Berlin: Springer, 1979:83-91.

135 Oehlert W. Biological significance of dysplastic epithelium and atrophic gastritis. In: Herfarth Ch, Schlag P, eds. Gastric cancer. Berlin: Springer, 1979:99-105.

136 Risio M, Coverlizza S, Ferrari A, et al. Immunohistochemical study of epithelial cell proliferation in hyperplastic polyps, adenomas, and adenocarcinomas of the large bowel. Gastroenterology 1988;94:899-906.

137 Deschner EE, Maskens AP. Significance of the labelling index and labelling distribution as kinetic parameters in colorectal mucosa of cancer patients and DMH treated animals. Cancer 1982;50:1136-41.

138 Johnston PG, O'Brien MJ, Dervan PA, et al. Immunohistochemical analysis of cell kinetic parameters in colonic adenocarcinomas, adenomas, and normal mucosa. Hum Pathol 1989;20:696-700.

139 Bostick RM, Fosdick L, Grandits GA, et al. Colorectal epithelial cell proliferative kinetics and risk factors for colon cancer in sporadic adenoma patie

140 Kikuchi Y, Dinjens WN, Bosman FT. Proliferation and apoptosis in proliferative lesions of the colon and rectum. Virchows Arch 1997;431:111-17.

141 Fearon ER, Vogelstein B. A genetic model for colorectal tumorigenesis. Cell 1990;61:759-67.

142 Wasan HS, Park HS, Liu KC, et al. APC in the regulation of intestinal crypt fission. $\mathcal{F}$ Pathol 1998;185:246-55.

143 Jass JR, Ajioka Y, Radojkovic M, et al. Failure to detect colonic mucosal hyperproliferation in mutation positive members of a family with hereditary non-polyposis colorectal cancer. Histopathology 1997;30:201-7.

144 Garcia S, Park HS, Novelli M, et al. Field cancerisation, clonality and epithelial stem cells: the spread of mutated clones in epithelial sheets. $\mathcal{F}$ Pathol (in press). 